\section{Notes}

1. The author would like to thank an anonymous referee for helpful comments on an earlier version of this article.

\section{References}

Bakic-Hayden, Milica, and Robert M. Hayden. 1992. "Orientalist Variations on the Theme 'Balkans': Symbolic Geography in Recent Yugoslav Cultural Politics." Salvic Review 5l(1): 1-15.

Banac, Ivo. 1984. The National Question in Yugoslavia: Origins, History, Politics. Ithaca: Cornell University Press.

Bringa, Tone. 1995. Being Muslim the Bosnian Way: Identity and Community in a Central Bosnian Village. Princeton: Princeton University Press.

Carnegie Endowment for International Peace. 1993. The Other Balkan Wars. Washington, DC: Carnegie Endowment.

Chirot, Daniel, ed. 1989. The Origins of Backwardness in Eastem Europe. Los Angeles: University of California Press.

Cohen, Lenard J. 1995. Broken Bonds: Yugoslavia's Disintegration and Balkan Politics in Transition. 2nd ed. Boulder, CO: Westview.

Danforth, Loring M. 1995. The Macedonian Conflict. Princeton: Princeton University Press.

Deletant, Dennis. 1995. Ceausescu and the Securitate: Coercion and Dissent in Romania, 1965-1989. London: Hurst.

Friedman, Francine. 1996. The Bosnian Muslims: Denial of a Nation. Boulder, CO: Westview,
Gallagher, Tom. 1995. Romania after Ceausescu. Edinburgh: Edinburgh University Press.

Glenny, Misha. 1996. The Fall of Yugoslavia. 2nd ed. New York: Penguin.

Hall, Brian. 1996. "Rebecca West's War." New Yorker. April 15,74-84.

Hall, Derek. 1994. Albania and the Albanians. New York: Pinter Reference.

Jelavich, Barbara. 1983. History of the Balkans, Vol. 2: Twentieth Century. New York: Cambridge University Press.

Judah, Tim. 1997. The Serbs: History, Myth and the Destruction of Yugoslavia. New Haven: Yale University Press.

Kaplan, Robert D. 1993. Balkan Ghosts. London: Papermac.

Owen, David. 1995. Balkan Odyssey. London: Victor Gollancz.

Poulton, Hugh. 1995. Who Are the Macedonians? London: Hurst.

Ramet, Sabrina Petra. 1996. Balkan Babel: The Disintegration of Yugoslavia from the Death of Tito To Ethnic War. Boulder, CO: Westview.

Rieff, David. 1995. Slaughterhouse: Bosnia and the Failure of the West. New York: Touchstone.

Rothschild, Joseph. 1974. East Central Europe between the Two World Wars. Seattle: University of Washington Press.

Silber, Laura, and Allan Little. 1997. Yugoslavia: Death of a Nation. Rev. ed. New York: Penguin.

Stokes, Gale, John Lampe, and Dennison Rusinow, with Julie Mostov. 1996. "Instant History: Understanding the Wars of the Yugoslav Succession." Slavic Review 55(1): $136-60$.

Tanner, Marcus. 1997. Croatia: A Nation Forged in War. New Haven: Yale University Press.
Thompson, Mark. 1992. A Paper House: The Ending of Yugoslavia. London: Vintage.

Todorova, Maria N. 1997. Imagining the Balkans. New York: Oxford University Press.

Verdery, Katherine. 1991. National Ideology under Socialism: Identity and Cultural Politics in Ceausescu's Romania. Berkeley: University of California Press.

Vickers, Miranda. 1995. The Albanians: $A$ Modern History. London: I. B. Tauris.

West, Rebecca. [1940] 1993. Black Lamb and Grey Falcon: A Journey through Yugoslavia. London: Canongate Classics.

Wolff, Larry. 1994. Inventing Eastern Europe: The Map of Civilization on the Mind of the Enlightenment. Stanford: Stanford University Press.

Wolff, Robert Lee. 1974. The Balkans in Our Time. Cambridge: Harvard University Press.

Woodward, Susan L. 1995a. Balkan Tragedy: Chaos and Dissolution after the Cold War. Washington, DC: Brookings.

Woodward, Susan L. 1995b. Socialist Unemployment: The Political Economy of Yugoslavia, 1945-1990. Princeton: Princeton University Press.

\section{About the Author \\ Charles King is the Ion Ratiu Chair of Ro- manian Studies at Georgetown University. He is co-editor, with Neil Melvin, of Nations Abroad: Diaspora Politics in the Former Soviet Union (Westview, forthcoming), and is the author of numerous articles and book chap- ters on nationalism, the Balkans, Romania, and other subjects.}

\title{
Teaching Democratic Theory Democratically
}

\author{
Mark Mattern, Chapman University
}

Is the classroom appropriately democratized? ${ }^{1}$ To what extent, and in what ways? In this article, I review the results of one experiment in democratic education that may shed some light on these questions. Democratic education is not the same as education for democracy. Education for democracy can be, for example, courses in history and civics which give students basic knowledge requisite for informed participation in a contemporary democracy, but which retain the hierarchical, authoritarian, and elitist elements of traditional, undemocratic teaching. Democratic education, by contrast, entails power sharing within the classroom. Simply asking students their opinions, while a valuable exercise, is not an example of power sharing. Sharing power with students means offering them real choices about course content and process. It requires moving away, partially or wholly, from the hierarchical, authoritarian, and elitist elements that characterize most educational practices today in the United States. Democratic education involves increasing the level of personal responsibility assumed by students and giving the students real decision-making authority without threats of punitive reactions by the instructor.
Why democratize the classroom? First, democratic education better enables the development of democratic skills and dispositions. If students engage routinely in educational practices that teach passivity, deference to elites, acceptance of unaccountable authority and power, and comfort with undemocratic hierarchy, they internalize these traits and accept them as normal. The traditional "banking" model of education, ${ }^{2}$ involving the deposit of knowledge in students by an instructor, teaches these traits of passivity, deference to elites, acceptance of unaccountable authority and power, and 
comfort with undemocratic hierarchy. Alternatively, teaching critical intelligence, creative problem-solving skills, willingness to challenge authority and power, and an inclination to experiment with social forms rather than accept them uncritically requires that educational practices routinize these traits in the classroom. Second, many students learn through practical experience. Democratic theory might more easily be learned by including some experience in the practice of democracy and using this experience as the basis for critical reflection and analysis. The classroom can be used as a laboratory in which students learn democracy by doing it. Third, the division of social realms is at least somewhat arbitrary. There is no inherent rationale for reserving the principles and practices of democracy for a realm of government while denying their relevance in other realms such as education.

In a course on democratic theory, I eventually turned all power over to the students, reserving for myself only one vote equal in weight to the vote of every other student. Students ultimately decided what they would do for the course, how they would do it, and how they would be evaluated and by whom. A central premise of the course was that access to insight about issues in democratic theory could be gained by critically analyzing and reflecting upon experiences within the classroom. For example, what could we learn about the relation between power and participation in electoral arenas by focusing on the same relation as it appears in classroom discussions? Answering the question "why do some students dominate dicussions" might yield insights about why some participants dominate in electoral arenas. Analyzing the relation between student development and participation in classroom activities might help students understand the relation between citizen capacity and political participation. Students might gain analytical grip on the issues of majority and minority tyranny by focusing on the issues as they arose in the classroom. How would students respond, for example, when a majority of students made decisions contrary to the interests of a minority? Students might explore the question of civic virtue by discussing whether or not this course could work without significant willingness by students to commit to the course and to balance their personal needs and interests with the needs and interests of other students. Editors of the campus newspaper were asked to serve as "media watchdogs" over this democratic experiment, as a way of potentially generating insights among students about the role of the media in a democracy. In addition to this focus on process within the classroom, students read, discussed, presented, and wrote about issues in democratic theory.

The course began with me fully in control. Initially, I planned and carried out each day's activities, and played a traditional teaching role by lecturing and leading discussions. During this initial phase, students read and discussed assigned readings, ${ }^{3}$ and began reviewing and redesigning, in a strictly advisory capacity without decision-making authority, the syllabus-constitution that served as the blueprint for the course. In week four, students elected five student representatives who were charged with the responsibilities of approving or rejecting the final draft of the syllabus-constitution, and with subsequently planning course activities consistent with the syllabus-constitution. During this phase of the course, I served an executive role with the power of initiative and veto power over any decisions made by students representatives. The student representatives also held the power of initiative, decision making authority based on a majority vote of representatives, and the power to override the executive's veto with a twothirds vote. The representatives appointed members of a Supreme Court who were charged with maintaining consistency between class decisions and the syllabus-constitution, especially its "rigorous academic standards" clause, and whose decisions were binding. Although most decisions were made by majority vote of the representatives, amending the syllabus-constitution required a two-thirds vote of all the students. Student representatives could poll their constituents before a vote, but were not required to do so.

The similarity between this evolving structure within the classroom and the U.S. Constitution was not planned, but it is not surprising that students and the instructor would revert to familiar democratic forms. I nevertheless wanted the students to experiment with different forms of democratic organization. With that in mind, I resigned my executive position in the eighth week of the semester, leaving the students in full control of the classroom, albeit led still by student representatives. The syllabus-constitution called for a shift at some point during the semester to a direct democracy in which all students had the option of participating as equals in the determination of class content and process. However, the students later amended the syllabus-constitution to strike this clause, opting to remain in a representative system, in part because of their fear that the classroom would assume even more chaotic form that it sometimes did in representative form.

Students selected a variety of learning strategies. They discussed readings and films, made presentations based on shared and individual readings, and sometimes discussed current events and issues in light of themes in democratic theory. The mechanics of democracy occupied much of the students' time in the classroom as they brainstormed and chose options for learning, finetuned the evaluation process, and argued and debated over different directions to take. The class sometimes included design and process evaluations in which students critically reflected on their own and others' performance in the classroom, and in which the course design and process were scrutinized for their democratic or undemocratic implications. Overall, the students worked fairly carefully through the Held (1987) and Macpherson (1977) models of democracy, made several presentations and discussed them, and created a workable, sophisticated democratic classroom organization and process. 


\section{Rigorous Academic Standards}

Democratic education, in order to be valid, must be consistent with rigorous academic standards. Did this course achieve this consistency? According to students, it did on most indicators. Students believed that the class either met or exceeded rigorous academic standards in most areas including reading load, intellectual level of discussions and presentations, and work load. On the other hand, some students believed that the class fell below academic standards in timeliness, attendance, and student effort. Although students perceived a general problem in the areas of timeliness and attendance, their self-reporting did not confirm this. For example, approximately two-thirds of the students reported missing only $0-2$ class sessions, and all but one of the remaining students reported missing only 3-5 class sessions. Half of the students reported that they missed this class "about as often" as they missed their other classes, while $40 \%$ reported that they missed this class "less often" than other classes.

My own evaluation of students' adherence to rigorous academic standards is somewhat less sanguine. Most students apparently did very little reading for this course. Only one student reported having read $90-100 \%$ of the assigned readinga relatively meager three books and one article-while $25 \%$ of the students read $75-90 \%$, and a solid majority of $55 \%$ completed ony $50-75 \%$ of the readings. However, three-fourths of the students also reported that they read "about the same amount" of the assigned readings for this course as they did in other classes, suggesting that, if students fell below rigorous academic standards in terms of reading load in this course, they also did so routinely in other courses.

In terms of students' overall work loads, it appeared that at least some students either barely met rigorous academic standards or fell below them. I had the impression that most of the work for this class occurred in the classroom, and that at least some students did relatively little work outside the classroom. This was especially evident in the presentations on the Held and Macpherson books which, with some exceptions, tended to reflect a substantial lack of preparation. On the other hand, many of the students spent significant amounts of time outside of the classroom meeting in committees, writing journals and papers, doing evaluation work, and doing other activities essential for running a course democratically.

In my estimation, students met rigorous academic standards in discussions, presentations on topics other than the models of democracy, and attendance. Generally, the discussions were very good, marred only by a tendency among some students to dissolve into side conversations and by a tendency of some students to dominate the conversations. Student presentations, on topics other than the models of democracy, also showed flashes of brilliance in the quality of the presentations and the discussions that they stimulated. On the other hand, several of the presentations seemed to have been prepared for other classes and simply rerun for this class. Overall, I was impressed by the commitment among most students to regular attendance, and more generally to the apparent commitment among most students to making the class a successful experiment. Although students good-naturedly began at the outset playing around with ideas for "having a good time, dude!" while losing the focus on education, they never seriously pursued any irresponsible options.

Students created evaluation committees in the four areas of participation, presentations, journals, and papers. Each students was randomly assigned to one of these grading committees. Students also created an Executive Evaluation Committee, comprised of one representative from each evaluation committee, to oversee the system, to act as an appeals body, and to tabulate final grades and report them to the registrar. The students appointed me as a final "court of appeals," unnecessarily as it turned out, since no student appealed his or her grade. Each student was given extensive choice in how she or he would be graded. Each student was allowed to select the weightings assigned to each area ranging initially from $15 \%$ to $40 \%$, depending on the category and, after the journals requirement was abolished midway through the semester, from $0 \%$ to $40 \%$. Strengths of this system included ensuring that everyone participated in the grading, allowing students extensive choice in how they would be evaluated, and allowing students to play to their own strengths. Weaknesses included the fact that some students' grading loads were considerably heavier than others. For example, the members of the presentations and participation committees had relatively little to do outside of class time, while members of the papers and journals committees had considerable reading to do outside of class. An additional potential weakness that looms large for many educators is the question of whether or not students are capable of adequately evaluating other students' work.

While all of the students rejected (on the final evaluation) the claim that they took the course because they wanted an easy grade of $A$, by the end of the course there were nevertheless strong expectations among the students of receiving a good grade. Eighty-five percent of the students who responded on the course evaluation, which was administered on the next-to-last day of class, indicated that they deserved a course grade of A or A-. Approximately $60 \%$ of the students actually received a course grade of $\mathrm{A}$ or $\mathrm{A}-$ from their peers, and most of the rest of the students fared only slightly worse, receiving a course grade of B + . Did the students earn these high grades? It depends on the criteria for evaluation. Based on students' own self-evaluations, the grade that they anticipated receiving was "about right" for $90 \%$ of the students based on how much they learned, and $95 \%$ of the students based on the amount of work that they did. Based on my own private evaluations of the quality of written essays, journal entries, presentations, and participation in discussions, there was a slight amount of grade inflation ranging from approximately .35 of a letter grade on written essays to approximately .15 of a letter grade on participation. The average overall course grade assigned by stu- 
dents was a relatively meager .24 of a letter grade higher than that which I assigned privately for purposes of comparison.

Several caveats are in order. First, it is possible that my own evaluations of students were too generous. I entered the semester with a commitment to protecting students from potential abuses that could have arisen in this democratic experiment. I encouraged leniency, counseling students to err on the side of generosity, citing the experimental nature of the course and my reluctance to see any student pay a price for the potential abuses and frustrations that inevitably accompany such a course. Second, the aggregate data presented above obscure some specific problems in individual cases. For example, I suspected several instances of plagiarism in the essays but, in light of my commitment to non-intervention in the class, did not follow up on my suspicions. It is doubtful whether students have the experience and knowledge to recognize this problem when it arises. Less ominously, student evaluations of each other, which I generally found to be accurate or close to accurate, sometimes badly missed the mark in individual cases. Third, some of the papers and presentations did not obviously bear on the subject of democratic theory. I would have insisted more strenuously than the student graders that essayists and presenters explicitly tie their efforts to issues in democratic theory. It is probably difficult for students to make these necessary connections in a course in which they are being introduced to the topic for the first time themselves. Fourth, in at least some cases, I suspected that students used materials in this class that they had previously developed for other classes. Again, it may be difficult for students to recognize this problem when it occurs.

I am convinced that the students made a good faith effort to maintain the integrity of the grading system. Yet, this course does not resolve the questions of whether or not it is appropriate for students to evaluate each other's work and, if so, to what extent? On the one hand, I am tempted to do the grading myself in future iterations of the course. Although the students gained some insight into the problems of grading by doing it, they did not necessarily learn anything about democracy. Democracy must be consistent with rigorous academic standards, and recognizing that the instructor can-in most circumstances-do a better job of grading need not entail a departure from democracy. Rather, it only marks a pragmatic recognition of the instructor's more extensive training and experience in the subject matter and in evaluating students' grasp of it. While the students in this course did an admirable job of designing and implementing an ingenious evaluation system, there are reasons to believe that the task of grading is, under normal circumstances, best left to an instructor who, presumably, has a more extensive and profound understanding of the subject matter, has practice in recognizing academic misconduct, and who can better ensure that assignments are tied to the subject matter of the course. The caveats noted above suggest as much. On the other hand, reassuming control of grading would likely undermine the democratic premise of the class as I taught it. So long as the instructor does the grading, students' real power and choice are limited. Out of fear of reprisals from the instructor in the form of a reduced grade, students would be practically forced into adhering to the wishes of the instructor as they perceive them to be. They would likely see their real potential for initiative and creativity limited. This is a dilemma left unresolved by my experiences in this course, and I remain uncertain of how to handle it.

\section{Participation}

I initially hoped to tie the issue of classroom participation to the issue of political participation, and analyze different levels of classroom participation in terms of how they model different levels of political participation. This comparison proved less effective than I had hoped. I agree with the $80 \%$ of the students who felt that there was "a good level of participation by most students" in the classroom, if participation is defined broadly to include listening and participation in committees as well as participation in discussions and in sharing responsibility for presentations based on the readings. However, if participation is defined less broadly to only include participation in discussions and presentations, the picture looks less favorable. As $80 \%$ of the students agreed, "some students dominated the discussions" (the remaining 20\% responded "maybe"). Although $40 \%$ of the students "would have appreciated some additional effort to hear from quieter students," there was very little support for the idea that the dominant speakers should be silenced, either voluntarily or via intervention by others. Perhaps more revealingly, $45 \%$ of the students agreed or strongly agreed that "quiet students have only themselves to blame for not being heard." This suggests that, though I tried on several occasions, I failed to convince the students that there exists a relationship between power and participation in the classroom, in effect missing an opportunity to model the same relationship between power and political participation. Had I credibly and convincingly established the connection in the classroom, I may have been able to better challenge the view proffered by many of the students on the course evaluation that marginalized people in the United States political process "have only themselves to blame." I also attempted to connect participation in discussions to the issue of civic capacity and development of citizens' skills and dispositions for selfgovernment. However, I apparently failed either to convince students that non-participants were missing out on opportunities to develop their skills and self-confidence, or that it was the collective responsibility of students to intervene to do something about it. At least some students tended to revert, once again, to the argument that the opportunities for development and use of civic skills and capacities are evenly distributed in the United States and, if some choose not to exercise those opportunities, it is not others' responsibility. 


\section{What Did Students Actually Learn?}

Although $85 \%$ of the students agreed or strongly agreed that they "learned a lot" about democracy from the course, it is not entirely clear what they learned. It can be said with some assurance, based on the course evaluation, that students gained a greater appreciation for the philosophy of democratic education and for the mechanics of teaching that most instructors take for granted but of which most students tend to be unaware. Two-thirds of the students reported on the course evaluation that the course helped them become aware of the "culture of silence" (Freire 1990) that permeates traditional educational practices, while an additional $20 \%$ responded "maybe." Three-fourths of the students agreed that the course "opened [their] eyes to the problems associated with a banking approach to learning where the instructor "deposits' knowledge into students." It can also be said with some assurance that, if students held simplistic of democracy, the course challenged the students to reconsider those views. Ninety percent of the students developed a healthy awareness that "democracy is more complicated" than they used to think. Students reported learning from participating in the design and delivery of a democratic course, with its emphasis on process, that democracy requires substantial individual initiative and responsibility. In open-ended, qualitative questions, students also claimed to have learned that democracy is complex, difficult, and messy; how to work with people they do not necessarily get along with; and more about the challenges of democratic processes.

I am less certain of how much of the substance of democratic theory students learned in this course. I am alarmed to report that nearly half of the students insisted, at the end of the course, that "we have equal opportunity in the United States," even though the overwhelming evidence (some of it presented and discussed in class) suggests that we fall well short of an ideal of equal opportunity. Also alarming is that $27 \%$ of the students agreed that "political equality is a reality, not merely a formality, in the United States," and an additional $21 \%$ were not sure. One in four students incorrectly believed that the United States is completely democratic, and nearly one in three incorrectly accused Cuba of being "completely undemocratic." Finally, 20\% of the students would not admit that "economic power buys political power in the United States," and $15 \%$ of the students disagreed that "equality is a fundamental requirement of democracy." These are basic questions of democratic theory that were amply addressed in this course, and the failure of some students to grasp or accept them is troubling. ${ }^{4}$ Of course, instructors using traditional, nondemocratic teaching methods frequently encounter equally stubborn, persistent imperviousness to facts and critical argument. In other words, it is not clear that a traditional teaching approach would have resulted in more accurate responses on these substantive issues.

\section{Student Satisfaction}

The students registered strong overall satisfaction with and approval of the course. Seventy percent of the students either agreed or strongly agreed that they "would recommend this same course to others." Approximately two-thirds of the students indicated that they "would like to be involved in more democratically organized and run classes." Eighty percent of the students agreed or strongly agreed that democratizing the classroom helped them learn about democracy. Half of the students either agreed or strongly agreed, compared to $15 \%$ who disagreed or strongly disagreed, that "democracy is appropriate in the classroom." When asked more modestly if "some democracy in the classroom is better than none," $80 \%$ of the students agreed or strongly agreed. Among the strengths of the course, students listed discussions and debates, student leadership and initiative, student presentations, the instructor's restraint, the overall level of student participation, and student freedom to run a course as they wanted to run it. Weaknesses of the course, according to students, included the sometimes-chaotic nature of class, fears over grading and time required to do it, a perception that some students took advantage of their freedom, and the perception of a lack of respect for peers shown at times in the classroom. The dissenters in this chorus of approval included one to three students, depending on the specific issue, who felt that the class failed to live up to their hopes for it. Among their criticisms were a perception that the focus on process in the classroom was "too much like high school," that too many students used the course as an opportunity to avoid doing work while still receiving a grade of A, that democracy in the classroom was too chaotic and the fruits too intangible, and that students showed too little responsibility and restraint.

\section{Conclusions}

This course amply demonstrates that most students are capable of assuming more responsibility for their own education. I found that students were genuinely interested in this course and its subject matter, and genuinely enthusiastic about making it a successful educational experience. The most significant shortcoming of the course was my failure to sustain the critical focus on course design and process. These routine evaluations of design and process were an essential premise for learning in this course. As a result, many of the insights that I had hoped to draw from the in-class design and process work were never generated or incompletely developed. For example, how did students feel about the unaccountable power of their Supreme Court? Did students feel that they made the right decision in remaining in a representative system? Would they have felt more equal had they converted the class to a direct democracy? If yes, do they think that this greater equality might have been achieved at the expense of getting substantive work done in the classroom? What changes would make it easier for silent students to participate in discussions? For each of these ques- 
tions, what insights can we glean about democracy by answering them? While the students addressed some of these questions, they had too little time to address others. The time limits that we faced always loomed rather large, making it more likely that we would shunt the design and process evaluations aside in the interests of squeezing in another model of democracy or another student presentation. This suggests that the course would work better as a two-semester offering.

Finally, this and other courses need not be democratized as completely as I did in this experiment. Educational practices can be partly democratized, consonant with time constraints, the subject matter, and the level of willingness and preparation of students. While it is clear that students in this course were both willing and able to shoulder more responsibility for their own learning, the shift from my shoulders to theirs need not be as extensive as it was in this course.

\section{Notes}

1. I would like to thank the students and colleagues who participated in and critically evaluated this experiment in democratic education for their commitment, enthusiasm, patience, good humor, creativity, and critical commentary on the course.

2. See Paolo Freire (1990). Alternatively, John Dewey used the metaphors of studentas-cistern into which the instructor pours knowledge; student-as-blank phonograph onto which the instructor etches knowledge; and student-as-sponge who soaks up the knowledge provided by the instructor (see Boydston 1990).

3. In order to jumpstart the course, I ordered three books before the semester. These were David Held, Models of Democracy (1987); Paolo Freire, Pedagogy of the Oppressed (1990); and C. B. Macpherson, The Life and Times of Liberal Democracy (1977). I also assigned John Dewey's essay entitled "The Need for a Philosophy of Education" (1934).

4. It is possible that the students who responded incorrectly to these questions did so not because they misunderstood the points but because, for ideological or other reasons, they simply refused to accept them as valid. Most of these students were reared in ideologically conservative and libertarian Orange County, and at least some tend to embrace their political beliefs rather uncritically.

\section{Teaching Iran-Contra: Further Reflections}

\section{Ronald H. Chilcote, University of California-Riverside}

My brief essay departs from the useful discussion by John Scott Masker on his experience teaching the Iran-Contra affair which appeared in PS (1996, 701-03). Masker incorporated a six-week unit in a semester course on U.S. foreign policy, whereas I have incorporated the Iran-Contra scandal into both quarter and semester courses on the U.S. and Latin American relations. Thus, there are similarities and differences in our approaches to this theme.

Our approaches run somewhat parallel in our recognition of the significance of the scandal for studying, understanding, and gaining insights into the formulation, manipulation, and practice of U.S. foreign policy along with permitting discussion of presidential leadership styles, congressional inquiry, congressional- executive tensions, bureaucratic politics, and public reaction and opinion. We agree that testimonials and memoirs by many of the principal participants in the affair constitute an extraordinary source of material, and we have had to refine the mass of information on the subject in order to facilitate and motivate students in the busy task of making sense of the mostly covert activities. We also have grappled with how to involve students in serious thinking about implications and moving toward some analysis of the complex case. Our classroom experiences have led us away from standard lecture and discussion formats and toward a pedagogy that emphasizes frequent writing tasks, student choice in readings, video tapes of the congressional hearings, and

\section{References}

Boydston, Jo Ann, ed. 1990. John Dewey: The Later Works, 1925-1953. Vol. 9. Carbondale, IL: Southern Illinois University Press.

Freire, Paolo. 1990. Pedagogy of the Oppressed. New York: Continuum.

Held, David. 1987. Models for Democracy. Stanford: Stanford University Press.

Macpherson, C. B. 1977. The Life and Times of Liberal Democracy. Oxford: Oxford University Press.

\section{About the Author \\ Mark Mattern is as- sistant professor of political science at Chapman University. $\mathrm{He}$ is the author of Acting in Concert: $\mathrm{Mu}$ - sic, Community and Political Action (Rut- gers University Press, 1998). His current research interests in- clude John Dewey's work on art, and workplace democracy in the Minnesota "new wave" cooperatives.

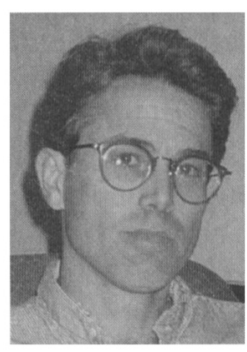

group discussion and problem-solving with frequent shifting between full class and small group activity. In short, our methods include case study, student-centered cooperative learning, and individual writing on many tasks. Whatever our relative successes in the classroom, I suspect that Masker would agree with my emphasis on encouraging basic skills such as writing, articulate speaking, synthesizing diverse material, critical thinking, and analyzing.

Our differences in approach are both substantive and pedagogical. I build the Iran-Contra case out of a general overview to U.S. foreign policy in Latin America, beginning with the Monroe Doctrine of 1823, touching upon Manifest Destiny during the 19th century, and progressing through the Good Neighbor Policy 